\section{Re: En kvinne i 40-årene med kreft, synkope og kramper}

Warsame og medarbeideres kasuistikk i Tidsskriftet nr. 19 (1) er enda et eksempel på at naturmedisin, kosttilskudd og lignende produkter ikke uten videre kan aksepteres som bivirkningsfrie. I tillegg viser kasuistikken at bivirkningsfokus hos helsepersonell er viktig $i$ et overvåkningsperspektiv. Ved å melde fra om mistenkte bivirkninger bidrar leger og annet helsepersonell til at signaler raskt kan fanges opp og systematiseres, og tiltak iverksettes.

Bivirkninger registrert i Norge samles i en nasjonal database, og videreformidles herfra til europeiske legemiddelmyndigheter og Verdens helseorganisasjon (WHO). Statistiske analyser på store datamaterialer gir en raskere signalgenerering enn om hvert land bare skulle samle sine «egne» tilfeller. Resultatet av meldingene kan være utsendelse av «Kjære helsepersonell»-brev, endring av preparatomtalen, innføring av nye forsiktighetsregler, kontraindikasjoner eller forskrivningsregler, pålegg til legemiddelprodusentene om å gjøre nye analyser eller utføre flere studier, eller om å trekke legemidlet fra markedet. For naturmidler og lignende er dokumentasjonskrav for effekt, sikkerhet og kvalitet så godt som fraværende. Årvåkne klinikere er i mange tilfeller en forutsetning for å oppdage sjeldne eller alvorlige bivirkninger, og spontanrapportering av mistenkte bivirkninger er et veldig viktig verktøy i legemiddelovervåkningsarbeidet. Dessverre er det bare om lag $5 \%$ av de alvorlige legemiddelbivirkningene som rapporteres (2). For naturmidler, kosttilskudd og lignende er tallene trolig enda lavere (3).

Vi oppfordrer helsepersonell til å melde fra ved enhver mistanke om alvorlige bivirkninger både av legemidler og av naturmidler og lignende produkter. Vi understreker at mistanke er nok til å melde; en eventuell årsakssammenheng blir også vurdert av oss etter internasjonale kriterier. Meldeskjema for mistenkte bivirkninger finnes integrert i enkelte journalsystemer, samt på www.relis.no og på www.legemiddelverket.no. RELIS mottar også bivirkningsmeldinger på telefon.

\section{Trude Giverhaug \\ trude.giverhaug@unn.no \\ Terje Nilsen}

Trude Giverhaug (f. 1963) er cand.pharm/dr.scient og leder i RELIS NordNorge.

Ingen oppgitte interessekonflikter

Terje Nilsen (f. 1979) er cand.pharm og rådgiver i RELIS Nord-Norge. Ingen oppgitte interessekonflikter.

\section{Litteratur}

1. Warsame MO, Gamboa D, Nielsen EW. En kvinne i 40-årene med kreft, synkope og kramper. Tidsskr Nor Legeforen 2014; 134: 1855-7.

2. Norsk legemiddelhåndbok for helsepersonell. Bivirkninger og legemiddelovervåking. http://legemiddelhandboka.no/ (Sist endret: 26. september 2014).

3. Nergård CS. Bivirkninger av plantebaserte produkter. Norsk Farmaceutisk Tidsskrift 2013; 7-8: 36-40.

\section{Re: En kvinne i 40-årene med kreft, synkope og kramper}

I denne artikkelen beskrives en pasient som har fått en tvilsom behandling hos en alternativ behandler (1), men det går ikke frem hvor «behandlingen» fant sted. Er det offentliggjort hvem som er ansvarlig for feilbehandlingen av pasienten? Er behandler anmeldt for brudd på loven om «alternativ» behandling? I tilfelle - fikk dette noen konsekvenser?

\section{Øystein Gudim}

og@adopsjonsforum.no

Øystein Gudim (f. 1955) er opptatt av problematikken fra et pårørendes perspektiv.

Ingen oppgitte interessekonflikter
Litteratur

1. Warsame MO, Gamboa D, Nielsen EW. En kvinne i 40-årene med kreft, synkope og kramper. Tidsskr Nor Legeforen 2014; 134: 1855-7.

\section{Re: En kvinne i 40-årene med kreft, synkope og kramper}

Jeg savner en opplysning i denne artikkelen (1): Er den alternative «behandleren» som sto bak denne livsfarlige behandlingen meldt til politiet eller Helsetilsynet, og hva slags straff fikk han? Og hvis vedkommende ikke er anmeldt, hva er årsaken?

\section{Pernille Nylehn \\ pernille@kleppnett.no}

Pernille Nylehn (f. 1964) er lege i spesialisering ved Haugesund sjukehus Ingen oppgitte interessekonflikter.

\section{Litteratur}

1. Warsame MO, Gamboa D, Nielsen EW. En kvinne i 40-årene med kreft, synkope og kramper. Tidsskr Nor Legeforen 2014; 134: 1855-7.

\section{Warsame og medarbeidere svarer:}

Pasienten oppga ikke navnet til den alternative behandleren. Hun hadde heller ikke direkte kontakt med behandleren, da kontakten gikk gjennom en bekjent.

\section{Mahad Omar Warsame}

mahadwarsame@hotmail.com

Danil Gamboa

Erik Waaeg Nielsen

Mahad Omar Warsame (f. 1975) er lege i spesialisering ved Akershus universitetssykehus.

Ingen oppgitte interessekonflikter.

Danil Gamboa (f. 1988) er lege ved Legevakten i Oslo.

Ingen oppgitte interessekonflikter.

Erik Waage Nielsen (f. 1956) er overlege og professor ved Akuttmedisinsk avdeling, Nordlandssykehuset Bodø og Institutt for klinisk medisin, Universitetet i Troms $\varnothing$.

Ingen oppgitte interessekonflikter.

\section{Re: Uetisk av nevrologene ikke å tilby pasienter med multippel sklerose cytostatikabehandling med autolog stamcellestøtte}

Vi mener Sigbjørn Rogne gir et feilaktig bilde av at norske nevrologer ikke ønsker å tilby cytostatika-behandling med autolog stamcelletransplantasjon (HSCT) til pasienter med multippel sklerose (MS) i sin kommentarartikkel i Tidsskriftet nr. 202014 (1). Norske nevrologer arbeider aktivt for å etablere tilbud om HSCT til MSpasienter som vi tror er best tjent med slik behandling. Som Rogne skriver, utføres HSCT ved hematologiske avdelinger/seksjoner. Hematologene har vurdert at det bør gjøres en nasjonal metodevurdering av HSCT ved MS, og Kunnskapssenteret for helsetjenesten arbeider nå med dette.

Norske nevrologer, hematologer og immunologer tok initiativ til en studie av HSCT ved MS allerede på nittitallet. Dessverre lyktes det ikke å skaffe finansiering. Den gang var behandlingsmulighetene ved MS svært begrensede. Siden har vi fått flere immunmodulerende medikamenter, inkludert monoklonale antistoffer som hemmer nøkkelmolekyler eller dreper viktige celler i sykdomsprosessen. Sykdommen kan dermed stabiliseres hos en betydelig andel 
av pasientene. Medikamentene tolereres ofte godt (2), og ved rett risikostratifisering kan en med rett valg av legemiddel med rimelig sikkerhet unngå alvorlige komplikasjoner. Denne utviklingen fortsetter og forandrer sannsynligvis i stor grad framtidsutsiktene for pasienter med MS.

Det er ikke foretatt noen placebokontrollert studie av HSCT, og heller ikke noen sammenlignende studie mot etablert behandling. Siden etablerte monoklonale antistoffer har betydelig effekt, må en slik studie inkludere mange pasienter for å avklare om HSCT er bedre eller dårligere. Frykten for komplikasjoner ved HSCT har så langt hindret dette. Observasjonsstudiene viser lovende resultater for pasienter med svært aktiv attakkpreget MS (3). Disse er imidlertid små og mangler kontrollgruppe, og resultatene er derfor beheftet med betydelig usikkerhet. De gir ikke svar på om HSCT er mer effektiv eller har færre bivirkninger enn etablert behandling. Videre har vi sikker informasjon fra mange års oppfølging av tusenvis av pasienter om at risikoen ved etablert behandling er liten, og sannsynligvis lavere enn ved HSCT - selv om dødeligheten ved HSCT nå er lav.

I denne situasjonen kan vi ikke se at det er etisk riktig å tilby HSCT framfor etablert behandling. Vi opplever imidlertid at enkelte pasienter med attakkpreget MS fortsetter å ha alvorlige attakker til tross for optimal behandling. Vi arbeider derfor aktivt for å tilby HSCT til disse pasientene, og har allerede begynt å få noe erfaring med dette ved Haukeland universitetssykehus. Vi ønsker å gjøre dette på en måte som bidrar til økt kunnskap om denne behandlingsformen, slik at vi kan gi best mulig tilbud til våre pasienter.

\section{Trygve Holmøy \\ trygve.holmoy@medisin.uio.no \\ Kjell-Morten Myhr \\ Lars Bø}

Trygve Holmøy(f. 1960) er overlege og professor ved Nevrologisk avdeling, Akershus universitetssykehus, og sitter i referansegruppen for Nasjonal kompetansetjeneste for multippel sklerose.

Kjell-Morten Myhr (f.1963) er professor og overlege ved Nevrologisk avdeling Haukeland universitetssykehus. Han er registeransvarlig og tidligere leder for Nasjonal kompetansetjeneste for multippel sklerose.

Lars Bø (f.1964) er overlege og professor ved Haukeland universitetssykehus og leder av Nasjonal kompetansetjeneste for multippel sklerose.

Interessekonflikter: Forfatterne har mottatt kompensasjon for deltakelse i klinisk utprøving av legemidler, forskningsstøtte, forelesningshonorar eller reisestøtte fra Allergan, Almirall, Bayer Pharma, Biogen Idec og Genzyme/Sanofi Aventis, Merck Serono eller Teva, og har eller har hatt tillitsverv i MS-forbundets fagråd, Multiple Sclerosis International Federation (MSIF), European Academy of Neurology (EAN) Subspecialty Scientific Panel of Multiple Sclerosis, eller European Committee for Treatment and Research In Multiple Sclerosis (ECTRIMS).

\section{Litteratur}

1. Rogne S. Uetisk av nevrologene ikke å tilby pasienter med multippel sklerose cytostatikabehandling med autolog stamcellestøtte. Tidsskr Nor Legeforen 2014; 134: 1931-2

2. O'Connor PW, Oh J. Disease-modifying agents in multiple sclerosis. Handb Clin Neurol 2014; 122: 465-501.

3. Burman J, lacobaeus E, Svenningsson A et al. Autologous haematopoietic stem cell transplantation for aggressive multiple sclerosis: the Swedish experience. J Neurol Neurosurg Psychiatry 2014; 85: 1116-21.

\section{S. Rogne svarer:}

Multippel sklerose (MS) er en alvorlig sykdom hvor gjennomsnittlig levetid er redusert med 8-10 år $(1,2)$. Jeg og mange MSpasienter ønsker derfor den mest effektive behandlingen, HSCT, som kan stoppe sykdommen $(3,4)$ og som ikke er farligere enn de mest effektive bremsemedisinene. Bremsemedisinene påfører de aller fleste uttalte livskvalitetssenkende bivirkninger $(5,6)$ og kan ikke stoppe sykdommen. Det er også usikkert om de reduserer fremtidig funksjonstap $(7,8)$. Dette gjenspeiles i Holmøy og nevrologkollegaenes beskrivelse av bremsemedisinenes nåværende og fremtidige egenskaper, der de bruker ord som «sannsynligvis», «i stor grad», «stabilisere», «kan» og «en betydelig andel». MSpasienter risikerer hele tiden invalidiserende attakker, og når bremsemedisinene har så usikker effekt og så store bivirkninger, er HSCT et soleklart førstevalg for mange. Hematologene, som utfører HSCT, ønsker at flere får behandlingen, men nevrologene holder igjen.

Nevrologenes sterke preferanse for bremsemedisinene mener jeg skyldes påvirkning fra legemiddelfirmaene som produserer disse. Legemiddelfirmaene samarbeider tett med nevrologene, finansierer deres studier av sine bremsemedisiner, og kan påvirke forskningsog behandlingsvalg. Nevrologene opplyser i sitt svar at de ikke har forsket på HSCT fordi det ikke har lykkes å skaffe finansiering. Problemstillingen illustreres av de oppgitte interessekonfliktene i nevrologenes svar.

MS-forbundet og MS-pasientene har ikke registrert at norske nevrologer har vært pådrivere for HSCT eller for finansiering av HSCT. For å få fortgang i etablering av HSCT, har seksjonsoverlegen ved hematologisk seksjon (Haukeland) bedt Kunnskapssenteret om en metodevurdering. Til tross for bremsemedisinenes betydelige livskvalitetssenkende bivirkninger, har nevrologene utført svært få studier for å belyse dette. Jeg mener uttalelsen «Medikamentene tolereres ofte godt» viser at nevrologene bagatelliserer bremsemedisinenes bivirkninger. Opptil $45 \%$ av MS-pasientene klarer ikke å bruke etablert bremsemedisinbehandling (9-11).

Behandling med monoklonale antistoffer har ikke vist tilnærmelsesvis like god behandlingseffekt som HSCT (4). Studier på HSCT har alltid manglet finansiering, og antallet HSCT-behandlede er derfor begrenset. Det er ikke utført observasjonsstudier på HSCT av MS-pasienter med kortvarig sykdom og lav til moderat sykdomsaktivitet. Nevrologene kan derfor ikke argumentere mot at disse får HSCT med den begrunnelsen at MS-pasienter med kortvarig og hissig sykdom har best effekt. Det er godt mulig at MS-pasienter med kortvarig sykdom og lav til moderat sykdomsaktivitet har best effekt av HSCT.

Dagens etablerte bremsemedisinbehandling er av gode grunner ikke godt etablert. Jeg er uenig i nevrologenes begrunnelser for å HSCT-behandle kun fem til ti MS-pasienter årlig. Omtrent 350 personer får MS hvert år i Norge. HSCT peker seg ut som den klart beste behandlingen, og helsemyndighetene må snarest mulig legge til rette for at langt flere kan få HSCT. HSCT er langt rimeligere enn bremsemedisinbehandling, og vil antakelig også gi store samfunnsøkonomiske besparelser. Jeg mener nevrologenes behandlingspraksis gavner legemiddelfirmaene på bekostning av MS-pasientene og de regionale helseforetakene som betaler for bremsemedisinene.

\section{Sigbjørn Rogne}

Sigbjorn.Rogne@unn.no

Sigbjørn Rogne (f. 1965) er spesialist i fordøyelsessykdommer og i geriatri og arbeider som rådgivende lege ved Legeavdelingen, Medisinsk klinikk, Universitetssykehuset Nord-Norge.

Interessekonflikter: Han har selv multippel sklerose.

\section{Litteratur}

1. Myhr K, Beiske AG, Celius EG et al. Nasjonale faglige retningslinjer for diagnostikk, attakk- og sykdomsmodifiserende behandling av multippel sklerose. Nasjonale faglige retningslinjer 2011: 18.

2. Scalfari A, Knappertz V, Cutter $G$ et al. Mortality in patients with multiple sclerosis. Neurology 2013; 81: 184-92.

3. Berner I. Stamcellstransplantation gjorde Ida fri från MS. Sveriges radio 2013.

4. Burman J, lacobaeus E, Svenningsson A et al. Autologous haematopoietic stem cell transplantation for aggressive multiple sclerosis: the Swedish experience. J Neurol Neurosurg Psychiatry 2014: 85: 1116-21.

5. Baldo BA. Side effects of cytokines approved for therapy. Drug Saf 2014; 37 : $921-43$. 